\author{
Al-wardah: Jurnal Kajian Perempuan, Gender dan Agama \\ Volume: 12 Nomor: 1 \\ ISSN: 1907-2740, E-ISSN: 2613-9367 \\ DOI: $\mathrm{xxx} \mathrm{xxxx} \mathrm{xxxx}$
}

\title{
PENINGKATKAN KESETARAAN GENDER DI UKRAINA (OLEH UN WOMEN)
}

\author{
Noviyanti Soleman \\ Khonkhaen University Thailand \\ noviyantisoleman6@gmail.com \\ Rifki Elindawati \\ Khonkhaen University Thailand \\ Rifkielindawati19@gmail.com
}

\begin{abstract}
Abstrack
Ukraine is one of the UN members which had ratified the convention of elimination discrimination against women during 1979. This is followed by the significant number of discrimination against women, because of political and economic instability. In addition, the situation has been getting worse due to crimea annexation and millitary crisis. Thus, UN Women as the part of UN agencies for advancing gender equality takes action to support in eradicating women discrimination in Ukraine. To asses those condition, this research aims to analyze efforts of UN Women towards the issue, based on theory of the role of international organization by Cliver Archer.
\end{abstract}

Keywords : gender equality, women discrimination, CEDAW, UN Women, Ukraine

\begin{abstract}
Abstrak
Ukraina adalah salah satu anggota PBB yang telah meratifikasi konvensi penghapusan diskriminasi terhadap perempuan selama 1979. Ini diikuti oleh sejumlah besar diskriminasi terhadap perempuan, karena ketidakstabilan politik dan ekonomi. Selain itu, situasinya semakin buruk karena pencaplokan krimea dan krisis militer. Dengan demikian, Perempuan PBB sebagai bagian dari badan-badan PBB untuk memajukan kesetaraan gender mengambil tindakan untuk mendukung penghapusan diskriminasi perempuan di Ukraina. Untuk menilai kondisi tersebut, penelitian ini bertujuan untuk menganalisis upaya PBB Perempuan terhadap masalah ini, berdasarkan teori peran organisasi internasional oleh Cliver Archer.
\end{abstract}

Kata kunci: kesetaraan gender, diskriminasi perempuan, CEDAW, PBB Perempuan, Ukraina

\section{A. PENDAHULUAN}

Dalam mendukung agendanya untuk mencapai poin nomor lima SDGs, yaitu Gender Equality atau kesetaraan gender, Perserikatan Bangsa-Bangsa (PBB) pada tahun 1979, melalui Majelis Umumnya atau UN General Assembly mengadopsi instrumen internasional yaituThe Convention on the Elimination of All Forms of Discrimination 
Peningkatan Kesetaraan Gender...

against Women (CEDAW)atau Konvensi Penghapusan Segala Bentuk Diskriminasi terhadap Perempuan yang kemudian diberlakukan pada tanggal 3 Desember 1981. Dalam konvensi tersebut, 180 negara atau sekitar lebih dari sembilan puluh persen negara-negara anggota PBB. UN Women . (2011, 03 28).

Secara universal CEDAW menetapkan prinsip-prinsip persamaan hak antara laki-laki dan perempuan. Konvensi ini menetapkan persamaan hak untuk perempuan, terlepas dari status perkawinan mereka, di semua bidang, termasuk politik, sosial, budaya dan sipil. Konvensi mendorong diberlakukannya perundang-undangan nasional yang melarang diskriminasi dan mengadopsi tindakan-tindakan khusus sementara untuk mempercepat kesetaraan de facto antara laki-laki dan perempuan, termasuk merubah praktek-praktek kebiasaan dan budaya yang didasarkan pada inferioritas atau superioritas salah satu jenis kelamin atau peran stereotipe untuk perempuan dan lakilaki.

Dalam merealisasikan prinsip-prinsip CEDAW, UN Women yang merupakan bagian dari Perserikatan Bangsa Bangsa yang bertujuan untuk menangani permasalahan kesetaraan gender dan pemberdayaan perempuan memberikan standar global untuk mencapai kesetaraan gender yang berkerjasama dengan pemerintah, masyarakat untuk merancang hukum, kebijakan, program-program dan layanan untuk melaksanakan prinsip-prinsip tersebut.

UN Women menfokuskan kepada lima prioritas utama dalam menangani permasalahan gender yaitu meningkatkan kepemimpinan dan partisipasi perempuan, menghentikan kekerasan terhadap perempuan, melibatkan perempuan dalam semua aspek perdamaian dan keamanan, meningkatkan pemberdayaan ekonomi perempuan dan membuat kesetaraan gender penting dalam perencanaan dan penganggaran pembangunan nasional. UN Women. (t.thn.).

Sebagai salah satu negara yang menjadi peserta CEDAW dan berkomitment untuk melakukan kewajibannya dalam menghormati hukum, melindungi dan memenuhi hak asasi manusia adalah Ukraina. UNDP Ukraine. (2017, 01 30). Menjadi salah satu negara pecahan Uni Soviet, Ukraine mengalami kesulitan dalam melekasanakan pemerintahannya dan mengalami stagnasi ekonomi pada tahun 1996. Pada tahun-tahun 
berikutnya makin diperburuk dengan keadaan perselihan dengan Rusia mengenai semenanjung Krimea. Theguardian. (2014, 6 09).

Mengalami masalah politik dan ekonomi tersebut menyebabkan munculnya masalah baru, yaitu diskriminasi terhadap perempuan. Dalam kasus ini, kurangnya representasi perempuan dalam pemerintahan dan lapangan pekerjaan, hal ini dikarenakan banyaknya kekerasan dan konflik yang terjadi di Ukraina. UN Women Europe and Central Asia. (2017). Selainperaturan dan kebijakan yang bersifat diskriminatif, perempuan juga mengalami diskriminasi pada kesehariannya dikarenakan norma dan gender stereotip yang membatasi hak asasi mereka.

\section{B. TEORI ORGANISASI INTERNASIONAL}

Menurut Clive Archer (1983) organisasi internasional dapat didefinisikan sebagai sebuah struktur formal yang berkesinambungan, yang pembentukannya didasarkan pada perjanjian antar anggota-anggotanya dari dua atau lebih negara berdaulat untuk mencapai tujuan bersama dari para anggotanya. UNIKOM. (t.thn )

Archer menjabarkan tiga peran organisasi internasional, diantaranya:

a. Sebagai instrumen untuk mencapai kesepakatan, menekan intensitas konflik dan aksi koordinasi.

b. Sebagai arena untuk menghimpun, berkonsultasi dan inisiasi pembuat keputusan dan merumuskan kesepakatan internasional.

c. Sebagai aktor, organisasi internasional yang memiliki kemampuan dan juga sebagai aktor otonom yang bertidak dalam kapasitasnya sebagai organisasi internasional dan tidak lebih sebagai eksekutor kepentingan anggota.

\section{PERAN UN WOMEN DALAM UPAYA MENINGKATKAN KESETARAAN GENDER DI UKRAINA}

Dalam menangani isu kesetaraan gender dan pemberdayaan perempuan, UN Women menggunakan program 6 Main Impact areas yang menjadi fokus kerjanya. Diantaranya adalah kepemimpinan dan partisipasi politik, mengakhiri kekerasan terhadap perempuan, aksi perdamaian dan keamanan dan kemanusiaan, perencanaan dan anggaran nasional, pemberdayaan ekonomi dan norma global. UN Women. (t.thn.) 
Dari ke-enam fokus kerja UN Women, Ukraina termasuk dalam empat fokus kerja yaitu kepemimpinan dan partisipasi politik, mengakhiri kekerasan terhadap perempuan, aksi perdamaian \& keamanan \& kemanusiaan, perencanaan dan anggaran nasional.

Menghubungkan dengan yang telah dijabarkan oleh Archer, UN Women sebagai organisasi internasional memiliki kapasitas dalam menjalankan fungsi-fungsi tersebut. Pada poin pertama, Archer menjelaskan bahwa internasional organisasi berfungsi sebagai alat untuk mencapai kesepakatan, menekan intensitas konflik dan aksi organisasi. Permasalahan yang diangkat dalam hal ini adalahdiskriminasi terhadap perempuan di Ukraina.

Dalam menjalankan fungsinya, UN Women mengadakan beberapa program untuk mengurangi kekerasan terhadap perempuan yang terjadi di ukraina. Salah satunya program humanitarian needs assessments and planning, UN Women memfasilitasi gender mainstreamingsebagai pemenuhan kebutuhan manusia mendasar.UN Women berkejasama dalam mengorganisirmereka yang mengalami diskriminasi karena konfik, usia, disabilitas, etnik ataupun latar belakang lainnya. UN Women. (t.thn.). Perbedaan latar belakang menjadi alasan utama diskriminasi yang terjadi di Ukraina, UN Women untuk Eropa dan Asia Tengah telah mencatat bahwa 90\% dari kasus kekerasan merupakan kasus kekerasan terhadap wanita, hal ini diakibatkan oleh usia, disabilitas, etnik mioritas atau karena konflik. Hal ini jelas sangat bertolak belakang dengan hak asasi manusia.

UN Women juga turut berkontribusi dalam program "recovery and peacebuilding".Program tersebut termasuk ke salah satu action plan UN Women tentang Women, Peace \& Security.Pada program ini, UN Women menyediakan program pelatihan dan konsultasi mengenai kesetaraan gender dan juga pemberdayaan perempuan. Menindak lanjuti hal tersebut, pada Maret 2017, UN Women bekerjasama dengan kementerian dalam negeri Ukraina untuk melakukan pelatihan di kepolisian mengenai efisiensi layanan di Ukraina agar menjadi lebih responsif terhadap perbedaan kebutuhan dan kepentingan perempuan dan laki-laki. (UN Europe and Central Asia. (2017, 3 14).

Selain itu, UN Women juga menyelenggarakan longer term national reforms yaitu program jangka panjang untuk mempromosikan kesetaraan gender, hak perempuan dan juga akuntabilitas. Program tersebut meliputi dukungan dari UN 
Women untuk mempromosikan gender mainstream, khusunya untuk daerah-daerah yang terkena dampak konflik, seperti Donetsk dan Luhansk.UN Women juga memberikan bantuan berupa pemberdayaan masyarakat dalam menangani kasus kekerasan terhadap perempuan.

Pada tahun 2015, Ukraina menempati peringkat ke 67 dari 142 negara tentang kesetaraan gender. Peringkat tersebut menandakan bahwa permasalahan gender di Ukraina semakin menurun, mengingat pada tahun sebelumnya Ukraina menempati peringkat ke 56.( Ukranian Helsinki. (2016, April 25). Hal ini dipengaruhi oleh kondisi keamanan internal Ukraina. Beberapa waktu lalu Ukraina mengalami konflik internal seperti Crimea Annexation, konflik militer yang terjadi di Ukraina Timur, Krisis Ekonomi Sosial. Ukranian Helsinki. (2016, April 25). Konflik tersebut menyebabkan tingkat diskriminasi terhadap perempuan menjadi meningkat.

Berdasarkan data yang ada, 2015 merupakan tahun terakhir program "Increasing accountability in financing for gender equality-EU/UN Partnership on Gender Equality (2011-2015)". UNITED NATIONS. (t.thn.). Program tersebut merupakan program kerjasama Uni Eropa dan PBB dalam membantu mengatasi permasalahan kesetaraan gender secara finansial. Penurunan peringkat yang berarti memburuknya tingkat kesetaraan gender tidak sepantasnya terjadi, hal ini dikarenakan PBB dan juga Uni Eropa telah mengulurkan tangannya untuk membantu dalam menangani hal tersebut. Program yang berjalan selama lima tahun tersebut seharusnya membawa situasi kesetaraan gender di Ukraina membaik, bukan memburuk.

Poin kedua yang dijabarkan Archer adalah organisasi internasional berfungsi sebagai arena untuk menghimpun, berkonsultasi dan inisiasi pembuat keputusan dan merumuskan kesepakatan internasional. Maka bagaimana UN Women menjadi wadah untuk membantu negara anggota dalam memberi solusi dan mengatasi permasalah tentang kesetaraan gender dan pemberdayaan perempuan yang terjadi pada negara tersebut. Selain itu, UN Women juga dapat bertindak sebagai pemberi insiasi untuk pembuat keputusan (negara anggota) dan merumuskan suatu kesepakatan.

Sebagai negara anggota UN Women, Ukraina bertindak sesuai dengen prinsipprinsip CEDAW. Pemerintah Ukraina mengurangi tindak kekerasan terhadap perempuan melalui penambahan dan pembaruan beberapa aturan hukum yang berjalan 
pada negara tersebut, diantaranya:( OSCE Office for Democratic and Human Rights. (t.thn.)

a. Kutipan dalam konsttitusi

Constitution excerpts

Constitution of Ukraine (2004, amended 2016) (excerpts)

b. Undang-undang

Primary legislation

Law on ensuring Equal Rights and Opportunities of Women and Men (2005)

Decree on Improving the Work of Central and Local Executive Bodies and Ensuring the Equal Rights and Opportunities of Women and Men (2005)

c. Peraturan sekunder

Secondary legislation

Recommendations of the Parliamentary Hearings on Equal Rights and Opportunities (2007)

Conducting Gender and Legal Expert Examination (2007)

Provision on the Interagency Board on Family, Gender Equality, Demographic Development and Combating Human Trafficking (2007)

Recommendations of the Parliamentary Hearings on the Current Situation and the New Tasks in the Prevention of Gender Violence (2007)

d. Arsip nasional

Archives

State Program on Strengthening Gender Equality in Ukrainian Society until 2010 (2006)

Resolution on Adoption of the State Program on Strengthening Gender Equality in Ukrainian Society until 2010 (2006)

Poin terakhir yang menjadi pelengkap dari penjabaran Archer yaitu organisasi internasional sebagai aktor yang memiliki kemampuan dan juga sebagai aktor otonom yang bertidak dalam kapasitasnya sebagai organisasi internasional dan tidak lebih sebagai eksekutor kepentingan anggota. Hal ini berarti bahwa UN Women tidak diperbolehkan melewati kapasistasnya sebagai organisasi internasional atau pihak ketiga 
terhadap apa yang terjadi di Ukraina. UN Women hanya sebatas membantu Ukraina dari sisi luar, tanpa melakukan intervensi langsung. Hal ini justru menunjukan sisi kelemahan suatu organisasi internasional dalam menangani permasalahan negara anggota.

Melihat kembali pembahasan pada poin pertama dan kedua, segala upaya dari tahun ke tahun sudah dilakukan UN Women, namun semuanya tetap kembali ke negara tersebut. Sebagai organisasi internasional, UN Women tidak bisa dengan leluasa untuk mencampuri urusan internal Ukraina. Segala proses dan hasil akhirnya tetap kembali ke Ukraina atau pemerintah sebagai pemegang kekuasaan negara tersebut.

Fakta yang terjadi dilapangan adalah diskriminasi terhadap perempuan masih saja terjadi di Ukraina. Peningkatan jumlah presentase diskriminasi terhadap perempuan yang tak kunjung menurun, menunjukan bahwa upaya-upaya tersebut tidak terlaksana dengan baik. Sehingga dapat dikatakan bahwa UN Women belum dikatakan berhasil dalam menangani kasus kesetaraan gender yang terjadi di Ukraina, walaupun sebenarnya UN Women telah membantu dalam kapasistasnya sebagai organisasi internasional.

\section{SIMPULAN}

Melihat kembali penjabaran fungsi organisasi internasional yang dikemukakan oleh Archer, yang mana meliputi beberapa hal seperti menekan intensitas konflik, aksi koordinasi, inisiasi pembuat keputusan dan lain lain. Namun archer juga menekankan bahwa organisasi internasional harus tetap bersifat otonom dan tidak memaksa. UN Women telah berupaya untuk menjalakan fungsinya sebagai organisasi internasional berdasakan penjabaran Archer. Upaya-upaya yang dilakukan UN Women diantaranya humanitarian needs assessments and planning, recovery and peacebuilding, longer term national reformsdan sebagai pemberi insiasi untuk pembuat keputusan. Namun UN Women tidak memiliki kapasitas untuk intervensi Ukraina dalam mengikuti prinsip prinsip CEDAW untuk mengurangi tingkat kekerasan terhadap perempuan. 


\section{DAFTAR PUSTAKA}

OSCE Office for Democratic and Human Rights. (t.thn.). Ukraine Gender Equality. Diambil kembali dari LEGISLATIONLINE: http://www.legislationline.org/topics/topic/7/country/52

Theguardian. (2014, 6 09). Post-Soviet world: what you need to know about Ukraine. Diambil kembali dari Theguardian Web site: https://www.theguardian.com/world/2014/jun/09/-sp-post-soviet-world-need-toknow-ukraine

Ukranian Helshinki. (2016, April 25). Women's rights and gender equality in Ukraine. Diambil kembali dari Ukranian Helsinki Human Right Union: https://helsinki.org.ua/en/women-s-rights-and-gender-equality-in-ukraine/

UN Europe and Central Asia. (2017, 3 14). Diambil kembali dari UN Europe and Central Asia Web site: http://eca.unwomen.org/en/news/stories/2017/03/policeofficers-in-ukraine-trained-to-be-responsive-to-gender-based-violence

UN Women . (2011, 03 28). Resources and Publications. Diambil kembali dari UN Women Asia and the Pacific Web site: http://unwomenasiapacific.org/docs/cedaw/archive/general/20110328_CEDAW_texconv.pdf

UN Women. (t.thn.). About UN Women. Diambil kembali dari UN Women Web site: http://www.unwomen.org/en/about-us/about-un-women

UN Women. (t.thn.). Annual Report 2016-2017. Diambil kembali dari UN Women: http://annualreport.unwomen.org/en/2017

UN Women. (t.thn.). Eropa \& Central Asia. Diambil kembali dari UN Women: eca.unwomen.org/en/where-we-are/ukraine

UN Women Europe and Central Asia. (2017). Advancing Gender Equality in Ukraine UN Women in Ukraine. Diambil kembali dari UN Women Europe and Central Asia Web site: http://eca.unwomen.org/en/digitallibrary/publications/2017/06/un-women-in-ukraine\#view

UN Women. (t.thn.). Text of CEDAW. Diambil kembali dari UN WOMEN: http://www.un.org/womenwatch/daw/cedaw/cedaw.htm

UNDP Ukraine. (2017, 01 30). Six things you need to know about CEDAW (and women's rights) in U kraine. Diambil kembali dari UNDP Ukraine Web site: http://www.ua.undp.org/content/ukraine/en/home/presscenter/articles/2017/01/3 0/six-things-you-need-to-know-about-cedaw-and-women-s-rights-inukraine.html 
UNIKOM. (t.thn.). Digital Library UNIKOM. Diambil kembali dari UNIKOM Web site: http://elib.unikom.ac.id/files/disk1/455/jbptunikompp-gdl-adangsutri22714-10-13.bab-i.pdf

United Nations. (t.thn.). Gender Equality. Diambil kembali dari UN Ukraine Web site: http://un.org.ua/en/resident-coordinator-system/gender-equality

United Nations. (t.thn.). Overview. Diambil kembali dari UNITED NATIONS:

http://www.un.org/en/sections/about-un/overview/index.html

United Nations. (t.thn.). UN Women Activities in Ukraine. Diambil kembali dari UN Ukraine Web site: http://un.org.ua/en/information-centre/news/1570 